\title{
ЕКСПЕРИМЕНТАЛЬНА МЕДИЦИНА
}

\author{
(c) Bagmut I.Yu., Kolisnyk I.L., Titkova A.V., Rezunenko Yu.K., ${ }^{*}$ Boiagina O.D. * \\ UDK [616.36:611.018.1]-099 \\ DOI https://doi.org/10.31718/mep.2018.22.3-4.06

\section{THE DEVELOPMENT OF MEMBRANOUS PATHOLOGY OF HEPATOCYTES THE INFLUENCE OF INTOXICATION*}

\author{
Bagmut I.Yu., Kolisnyk I.L., Titkova A.V., Rezunenko Yu.K., * Boiagina O.D. * \\ Kharkiv Medical Academy of Postgraduate Education (Ukraine) \\ Kharkiv National Medical University (Ukraine)
}

The study was performed at the Department of Clinical Pathophysiology, Topographical Anatomy and Operative Surgery at Kharkiv Medical Academy of Postgraduate Education as a part of research project "Radiotoxins' pathochemical mechanisms and methods of early diagnostics and correction", state registration No. 0117 U000589.

We studied the subtoxic effect of small doses of sodium fluoride on the activity of microsomal hepatocytes on 30 Wistar rats' populations in subacute experiment. The intensity of lipid peroxidation (LPO) in liver of rats which were administered sodium fluoride orally for a long time at doses of 1/10 and 1/100 LD $D_{50}$, was evaluated by the content of its molecular products - diene conjugates (DC), and MDA-reagents Schiff bases. We found that oral administration of sodium fluoride to rats at doses of $1 / 10$ and $1 / 100 L D_{50}$ promotes a statistically significant increase $(r \leq 0,002)$ relative to the control group of animals in DC content during the entire period of observation. At a dose 1/10 LD 50 we observed the most significant increase in this indicator on the 10th day of the experiment - at 265\%, and at a dose $1 / 100 L D_{50}-$ on the 20 th day an average of $234 \%$. In rats' liver by the action of subtoxical dose of sodium fluoride at a dose of $1 / 10 L D_{50}$, starting from the 20th day, we detected a gradual increase ( $r \leq 0.001$ ) of TBA-reagents relative to control - for $27,41,78,133 \%$. Secondary end products and lipid peroxidation, which are defined under the long-term of sodium fluoride, somehow contribute to the disruption of the microstructure of hepatocytes membranes, their permeability, reduce their division, regeneration and inhibition of mitochondrial respiratory chain enzymes and microsomal monooxygenase system.

Keywords: free radical processes, lipid peroxidation, sodium fluoride, liver of rats.

На 30 щурах популяції Вістар досліджено в підгострому досліді дію малих субтоксичних доз фториду натрію на активність мікросом гепатоцитів. Про інтенсивність перекисного окислення ліпідів (ПОЛ) у печінці щурів, яким тривалий час перорально вводили фторид натрію у дозах $1 / 10$ i 1/100 LD тів - дієнових кон'югатів (ДК), ТБК-реактантів і шифових основ. 3 'ясовано, що пероральне введення щурам фториду натрію у дозах $1 / 10$ і $1 / 100$ LD 50 сприяє статистично значимому $(p \leq 0,002)$ по відношенню до контрольної групи тварин підвищенню вмісту дієнових кон 'югатів у всі терміни спостереження. У випадку дози $1 / 10 L D_{50}$ найбільш суттєвим збільшення цього показника спостерігалося на 10-ту добу експерименту - на $265 \%$, а у випадку дози 1/100 LD 50 - на 20-ту добу в середньому на $234 \%$ У печінці щурів, при дії субтоксичних дох фториду натрію - в дозі $1 / 10 L D_{50}$, починаючи з 20-ї доби, чітко визначалося поступове підвищення $(p \leq 0,001)$ рівня ТБКреактантів по відношенню до контролю - на 27, 41, 78, 133 \%. Вторинні та кінцеві продукти ПОЛ, що виявляються при тривалій дії фториду натрію, так чи інакше сприятимуть порушенню мікроструктури мембран гепатоцитів, їх проникності, зниженню їх ділення та регенерації, а також пригніченню активності ферментів мітохондріального дихального ланцюга та мікросомальної монооксигеназної системи.

Ключові слова: вільно радикальні процеси, перекисне окислення ліпідів, фрторид натрію, печінка щурів

\section{Introduction}

The main biological role of fluoride and its compounds consists in bone formation, formation of dentin, enamel, preventing the development of senile osteoporosis. High concentrations of fluoride stimulate lipid peroxidation and inhibit antioxidant defense system. It belongs to the elements of the first class of danger - especially hazardous chemicals. Prolonged excessive intake of fluoride compounds in the composition of the body can cause pathological condition - fluorosis. Despite the significant content of fluoride in different tissues of the human body, its physiological role so far has not been clarified.

The processes of free radical oxidation constitute an important part of nonspecific metabolic component of adaptation to the effects of stress factors, including chemi-

\footnotetext{
* To cite this English version: Bagmut I.Yu., Kolisnyk I.L., Titkova A.V., Rezunenko Yu.K. Boiagina O.D The development of
} membranous pathology under the influence of intoxication. // Problemy ekologii ta medytsyny. - 2018. - Vol 22, № 3-4. - P. 22-24. 
cal origin. Evidence of this position is confirmed by the nature of radical systems, especially on electron transport chain of endoplasmic reticulum and mitochondria. Adaptive adjustment of the oxygen metabolism due, for example, to stress, xenobiotics biotransformation accompanied usually by certain shifts in the mode of formation of free radical intermediates $[1,2,3]$.

The aim of this study is to investigate the state of free radical processes and lipid peroxidation in the liver of rats with chronic fluoride intoxication.

\section{Material and methods}

Studies were conducted on mature rats of Wistar line weighing 180-220 g, which were kept at hospital vivarium. Rats were subjected to oral seed probe using aqueous solutions of sodium fluoride (FS) once daily for 60 days at doses of 1/10,1/100 and 1/1000 LD 50 , which were under $20 \mathrm{mg} / \mathrm{kg}, 2 \mathrm{mg} / \mathrm{kg}$ and $0.2 \mathrm{mg} / \mathrm{kg}$ body weight (FS average lethal dose for rats received orally, is $200 \mathrm{mg} / \mathrm{kg}$ ). The animals in the control group were injected with appropriate amounts of drinking water. Research conducted indices 10, 20,30, 50 and 60 days after the start of the experiment. Each group had 10 animals. Rats were euthanized by decapitation with guillotine knife, pre-anesthetized with thiopental sodium 50 $\mathrm{mg} / \mathrm{kg}$.

The content of diene conjugates in rats' liver homogenate was evaluated by spectrophotometer at 233 $\mathrm{nm}$ with pre-extraction with heptane izopropanol mixture $[2,3,4]$. The content of diene conjugates was calculated based on the molar extinction coefficient $\varepsilon=2,2 \cdot 105$ mol$1 \mathrm{~cm}-1$.The content of TBA-reagents in rats' liver homogenate was determined by reaction between malondialdehyde and tiobarbiturats acid (TBA), which at high temperature and acidic environment is to form trymetynes colored complex with maximum absorption at a wavelength of $532 \mathrm{~nm}$ [5]. Number of TBA-calculated reagents was based on the molar extinction coefficient $\varepsilon=1,56 \cdot 105 \mathrm{~mol}-1 \mathrm{~cm}-1$. The level of Schiff bases - products of interaction of carbonyl compounds and amins groups of proteins, amino acids, nucleic acids - was measured in the liver homogenate by spectrofluorometer at a wave length of $360 \mathrm{~nm}$, excitation and emission wave length of $430 \mathrm{~nm}$ from the previous extraction by Folcha mixture (chloroform-methanol) [6].

Statistical analysis of the results was carried out using a computer application package for processing of statistical information Statistica 6.1 (StatSoft, Inc., USA).

\section{Results and discussion}

The level of free radical processes in the liver of rats, which during the 60 days were administered in doses of FS $1 / 10$ and $1 / 100 L_{50}$ was evaluated in the intensity of $\mathrm{H}_{2} \mathrm{O}_{2}$-induced chemiluminescence $(\mathrm{CL})$. On the 10th and 20th day of the experiment, we observed a statistically significant increase $(p<0.001)$ relative to the control rate of case of FS action at a dose $1 / 10 L D_{50}$, respectively, 37 and $134 \%$. On the 30 th day we registered a slight decrease $(37 \%)$ of $C L$ intensity in relation to the value of the previous observation period, but compared to control increase $(p<0.001)$ by $66 \%$. It is necessary to point out that on the 60th day of oral administration of FS to rats at doses $1 / 10 L_{50}$ there was a statistically significant $(p<0.001)$ reduction of $33 \%$ of $C L$ intensity in the liver of rats as compared with control. Action of FS at a dose $1 / 100 L_{50}$ was accompanied by a rather significant increase $(r \leq 0.002)$ when compared to control intensity su- perweak glow in all periods of observation, especially pronounced in the 30th day - an average of $85 \%$. In terms of level of intensity, following chemiluminescence in the liver of rats it gradually decreased and on the 60th day of FS administration it was $19 \%$.

It is proved that any disruption of dynamic equilibrium between pro- and antioxidants in many pathological conditions is displayed on CL intensity biological substrates $[4,5]$. Thus, the increase in intensity of rat liver homogenate CL for actions in the UNFPA doses of $1 / 10$ and $1 / 100 L D_{50}$ can be explained by a shift prooxidantantioxidant balance toward increased formation of prooxidant, including the AFC. However, recently the scientists have widely discussed the involvement of ROS in signal transduction from the receptors to the cell nucleus and ROS regulation being dependent on redox signaling system $[6,7,8]$.

The peculiarity of the latter is a property of ROS to cause the expression of genes, the products of which have antioxidant activity, which leads to increased buffer capacity and restoring redox homeostasis. However, the continued generation of abnormally large amounts of ROS can cause persistent changes in signal transduction and gene expression, impaired redox balance of the cells of oxidative stress, apoptosis and dysregulation as a consequence of pathological conditions.

One should emphasize the fact that a large number of ROS acts as inducers of oxidative damage to macromolecules basic cell, primarily proteins, in disruption of their functional activity [9]. Changing any component of redox homeostasis leading to its imbalance of compensatory reactions on the local level, which probably arises under conditions of FS effects on rats showed increased intensity and refrigerator. The prevalence of nonspecific oxidative stress in cells entails the use of energy substrates and proteins are important to balance the redox system. Depending on the length of oxidative stress and antioxidant system functional reserves depletion occurring in reparation and adaptation of the organism, which is probably on the 60th day of oral dose of FS $1 / 10 L_{50}$ and is confirmed by a reduction in the intensity of CL homogenate in rats' liver.

The intensity of LPO in liver of rats which were administered FS orally for a long time at doses $1 / 10$ and 1/100 $\mathrm{LD}_{50}$, was evaluated by the content of its molecular products - diene conjugates (DC), TBA-reagents and Schiff bases. The results showed that oral administration to rats in doses of FS $1 / 10$ and $1 / 100 L_{50}$ promotes statistically significant $(r \leq 0.002)$ relative to the control group of animals increase in GC content during the entire monitoring period. If the dose was $1 / 10 L_{50}$, the most significant increase in this indicator was observed on the 10th day of the experiment - at $265 \%$, and if the dose was $1 / 100 L_{50}$ on the 20th day - an average of $234 \%$. In the liver of rats FS toxification was also increasing the content of TBAreagents. On the 10th day of the experiment, there was an increase when compared with the value in control was unreliable for both doses $(p=0.059$ and $p=0.199)$. If the dose $1 / 10 L D_{50}$, starting from the 20th day, clearly defined gradual increase $(r \leq 0.001)$ of TBA-reagents relative to control - for $27,41,78,133 \%$. Similar dynamics was characterized by change and action to FS in a dose $1 / 100 \mathrm{LD}_{50}$ - an increase of TBA-reagents was $19,73,70$ and $99 \%$, respectively, on the 20th, 30th, 50th and 60th day of observation. On the 10th and 20th day of FS action at doses $1 / 10$ and $1 / 100 L_{50}$ when compared to control statistically significant changes in the content of 
the end products of lipid peroxidation - Schiff bases were observed. The results showed a significant gradual increase $(p<0.001)$ of this indicator on the 30th, 50th and 60 th day $-172,370$ and $380 \%$ respectively. A similar, but less pronounced dynamics was found to $1 / 100$ the dose $\mathrm{LD}_{50}-103,173$ and $169 \%$.

In general, the results obtained reflect the initiation of LPO process that can be regarded as a mechanism response on organism rats on long-term effect of FS. Dynamics of LPO products content has a certain dependence on the term of the FS. In the initial stages (10 and 20 days) oral doses of FS $1 / 10$ and $1 / 100 L_{50}$ recorded a marked increase in primary products of lipid peroxidation - DK, indicating the initial activation process. DK is the most volatile products of lipid peroxidation, increase of their level usually reflects the significant impact of the intensity of the pro-oxidant, such as ROS $[10,11]$.

The logical consequence of activation of lipid peroxidation in the liver of rats under FS action is to increase secondary products - TBA-reagents (especially since the 30th day), indicating a more intense and deep course of the process. But in rat liver, beginning with the 50th day, FS LPO activation is more pronounced at the formation of end products - Schiff bases, which are regarded as indicators of chronic processes of free radical oxidation. Secondary end products and lipid peroxidation, which are under long-term FS somehow contribute to the disruption of the microstructure of hepatocytes membranes their permeability, reduce their division, regeneration and inhibition of mitochondrial respiratory chain enzymes and microsomal monooxygenase system [12-15].

To confirm the orientation of the dynamics of lipid peroxidation in rats under conditions of prolonged exposure to doses of FS $1 / 10$ and $1 / 100 L D_{50}$ calculated the ratio Schiff bases/(DC+TBA-reagents). It proved statistically significant $(r \leq 0.016)$ relative to control reduction coefficient of 10 and 20 th day dose in steps UNFPA $1 / 10$ $\mathrm{LD}_{50}$ respectively 63 and $59 \%$, while 30,50 and 60th day, on the contrary, increased respectively by 16,92 and $120 \%$. In oral administration at a dose of FS $1 / 100 L_{50}$ value ratio decreased on the 10th, 20th and 30th day of the experiment (respectively 69,70 and $11 \%$ ) and on the 50 th and 60 th day - increased to 17 and $32 \%$ relative to control values.

Conclusion. The observed increase in the coefficient of correlation Schiff bases/(dienes+TBA-reagents) in the liver under the action of UNFPA clearly indicates the direction of LPO towards the formation of toxic end products - Schiff bases and reduce the activation of POL at the formation of primary and secondary products.

\section{References}

1. Sarma $A D$, Mallick $A R, G$ hosh $A K$, Free radicals and their role in different clinical conditions: an overview: IJPSR, 2010, Vol. 13: P. 185-192.

2. Meyerson FS. Adaptation Medicine: Mechanisms and Protective effects of adaptation - M .: Hypoxia Medical, 1993. $-331 \mathrm{p}$.

3. Dubinina Ye. Ye. Produkty metabolizma kisloroda v funktsional'noy aktivnosti kletok (zhizn' i smert', sozidaniye i razrusheniye). Fiziologicheskiye i klinikobiokhimicheskiye aspekty / Ye. Ye. Dubinina. - SPb.: Meditsinskaya pressa, 2006. - $400 \mathrm{~s}$.

4. Orehovych VN, Modern methods in biochemistry. - M., Medicine, 1977. - 371 p.

5. Zakaryan A.Ye. Razlichnyye metody khemilyuminestsentnogo analiza $v$ otsenke urovnya svobodnoradikal'nogo perekisnogo okisleniya lipoproteinov syvorotki krovi cheloveka pri razvitii patologicheskikh protsessov $v$ organizme / A. Ye. Zakaryan, Z. A. Zakaryan, A. A. Trchunyan // DNAN Armenii. - 2012. - T. 112, № 1. - S. 79-86.

6. Lesovskaya MI, Hemylyumynestsent antioxidant diagnosis and correction of health violations during oxidative stress; Modern scientific technology, 2010, № 7: P. 190192.

7. Kormosh N.G. Fiziologicheskaya rol' aktivnikh form kisloroda (subkletochnyy uríven') - viglyad klinitsista / N.G. Kormosh // Ross. Bioterapevticheskiy zhurnal. - 2011. - T. 10, № 4. - S. 29-35.

8. Martinovich G. G. Redoks-gomeostaz kletok / G. G. Martinovich, S. N. Martinovich // Uspekhi fiziologicheskikh nauk. - 2008. - T. 39, № 3. - S. 29-44.9. Ray PD, HuangBW, TsujiY,Reactive oxygen species (ROS) homeostasis and redox regulation in cellular signaling: Cell Signal., 2012, Vol. 24, № 5: P. 981-990.

9. Okislitel'nyy stress: patologicheskiye sostoyaniya i zabolevaniya / [Men'shchikova Ye. B., Zenkov N. K., Lankin V.Z. i dr.]. - Novosibirsk: ARTA, 2008. - $284 \mathrm{~s}$.

10. Zhi-Hua S,EtsuoN, Two faces of lipid peroxidation products: the -Yin and Yang-principles of oxidative stress: J. Exp. Integr. Med., 2011, Vol. 1 (4): P. 215-219.

11. Saha D,TamrakarA, Xenobiotics, oxidative stress, free radicals Vs. Antioxidants: dance of death to heaven's life: Asian J. Res. Pharm. Sci, 2011, Vol. 1, Iss. 2: P. 36-38.

12. Klimenko MO,KucheryavchenkoMO,Bagmut IYu,Zhukov $\mathrm{VI}$,Long subtoxical laproksyd influence on the metabolic activity of monooxygenase system hapatocyts in subacute experiment: Problems of continuing medical education and research, 2014, 4 [16]: P. 57-60.

13. Bagmut I. The impact on the state oligoesters mikrosomal monooxygenase system hepatocytes white rats in the experiment: Strategic question of Science, 2014: materials of international IX scientific conference. Polska , Przemysl: «Nauka and studia», 2014, V. 26: P. 41-45.

14. Bagmut IYu, Klimenko NA, Zhukov VI, The Effect on olygoephirs content on gonadotropic sexual hormonesinblood of white rats. High society school 2013: materials of IX international scientific conference - Bulgaria, Sofia, "ByalGRAD-BG" OOD, 2013, V. 37: P. 7-10.

Матеріал надійшов до редакції 12.07.2018 